Brazilian Journal of Microbiology (2009) 40: 505-521

ISSN 1517-8382

\title{
PHYLOGENETIC RELATIONSHIPS BETWEEN BACILLUS SPECIES AND RELATED GENERA INFERRED FROM 16S RDNA SEQUENCES
}

\author{
Wei Wang; Mi Sun* \\ Yellow Sea Fisheries Research Institute, Chinese Academy of Fishery Sciences, Qingdao, China \\ Submitted: July 14, 2008; Returned to authors for corrections: October 06, 2008; Approved: May 04, 2009.
}

\begin{abstract}
Neighbor-joining, maximum-parsimony, minimum-evolution, maximum-likelihood and Bayesian trees constructed based on 16S rDNA sequences of 181 type strains of Bacillus species and related taxa manifested nine phylogenetic groups. The phylogenetic analysis showed that Bacillus was not a monophyletic group. B. subtilis was in Group 1. Group 4, 6 and 8 respectively consisted of thermophiles, halophilic or halotolerant bacilli and alkaliphilic bacilli. Group 2, 4 and 8 consisting of Bacillus species and related genera demonstrated that the current taxonomic system did not agree well with the 16S rDNA evolutionary trees. The position of Caryophanaceae and Planococcaceae in Group 2 suggested that they might be transferred into Bacillaceae, and the heterogeneity of Group 2 implied that some Bacillus species in it might belong to several new genera. Group 9 was mainly comprised of the genera (excluding Bacillus) of Bacillaceae, so some Bacillus species in Group 9: B. salarius, B. qingdaonensis and B. thermcloacae might not belong to Bacillus. Four Bacillus species, B. schlegelii, B. tusciae, B. edaphicus and B. mucilaginosus were clearly placed outside the nine groups.
\end{abstract}

Keywords: Bacillus phylogeny; Bayesian inference; Evolutionary trees; 16S rDNA

\section{INTRODUCTION}

In recent years, numerous new species of genus Bacillus were reported and at the same time, many new genera of Bacillaceae were established. According to List of Prokaryotic names with Standing in Nomenclature (LPSN, http://www.bacterio.net) (6), of more than 140 Bacillus species, there were only 54 species reported before 2000; and of more than 30 genera of Bacillaceae, only six genera were established before 2000. Bacillus has long been regarded as a phylogenetic heterogeneous group (1). However, the phylogeny of the new Bacillus species and the new genera of Bacillaceae have not been roundly studied.

Numerical classification based on a series of phenetic characters was used for classification of 368 Bacillus strains into 79 clusters (23). After 1990, 16S rDNA has been successfully applied in determining phylogenetic 
Wang, W. et al.

relationships of the aerobic, endospore-forming bacteria, which played an important role in the creation of several families and genera of Bacillales (7).

Nowadays $16 \mathrm{~S}$ rDNA is a vital standard for taxonomy of the bacteria. Goto et al (9) used partial 16S rDNA sequence for rapid identification of Bacillus species. Then Xu and Côté (34) used 3' end 16S rDNA and 5' end 16S-23S ITS nucleotide sequences to infer phylogenetic relationships among Bacillus species and related genera. However, the two phylogenetic trees from the above two papers did not seem to be convincing because of less DNA sequences (69 and 40, respectively) and short sequence lengths (1057 bp and 220 $\mathrm{bp}$, respectively). Almost complete $16 \mathrm{~S}$ rDNA sequences with high quality from recently reported Bacillus species are accessible in GenBank, which become ideal data for phylogenetic analyses. Moreover, new softwares $(25,28)$ executing Bayesian or ML algorithm (11) and personal computer hardwares with high computing capability facilitate further study on phylogeny.

The primary aim of the current investigation was to establish phylogenetic relationships between Bacillus species and related genera by reconstructing 16S rDNA phylogenetic trees using several algorithms.

\section{MATERIALS AND METHODS}

Bacillus species, type species of the genera of Bacillaceae and type species of some families in Bacillales were selected for the phylogenetic study (LPSN updated date September 04, 2007). The $16 \mathrm{~S}$ rDNA sequences of the type strains of the bacteria mentioned above were downloaded from the GenBank. If several 16S rDNA sequences from the type strain(s) of the same species were available, the longest one with the least non-AGTC characters would be selected. All the rectifiable ambiguous nucleotides in the selected sequences were corrected according to the homologous sequences searched by BLAST (http://130.14.29.110/BLAST/) and/or other 16S rDNA sequences of the type strain(s).

Nucleotide sequence alignments were made using ClustalX 1.83 (32) and optimized using Tune ClustalX (Hall 2004 ,

http://homepage.mac.com/barryghall/TuneClustalX.html) by modifying multiple alignment parameters. Then Bioedit 7 (10) was used for refining the entire alignment by eye. Calculations of pairwise $16 \mathrm{~S}$ rDNA sequences similarity were achieved using the EzTaxon server (http://www.eztaxon.org/) (4). Escherichia coli was used as the outgroup. The optimal models of nucleotide substitutions were estimated by the program Modeltest 3.7 (22), using hierarchical likelihood ratio tests (hLRT) and the Akaike Information Criterion (AIC).

Neighbor-joining (NJ), maximum-parsimony (MP) and minimum-evolution (ME) analyses were performed with MEGA 4 (29). NJ and ME analyses were performed using the maximum composite likelihood method and 1000 bootstrap replications. Maximum likelihood (ML)-based phylogenetic analyses were performed with RAxML-VI-HPC 4 (http://phylobench.vital-it.ch/raxml-bb/) using default parameters (bootstrap $=100$ ). Bayesian trees were inferred using MrBayes 3.1.2 (25) according to the MrBayes 3.1 Manual (2005). All the Markov chain Monte Carlo searches were run with four chains for 4,300,000 generations, with trees being sampled every 100 generations. The first 30000 trees were discarded as "burnin", keeping only trees generated well after those parameters stabilized.

\section{RESULTS AND DISCUSSION}

$18216 \mathrm{~S}$ rDNA sequences were selected but the $16 \mathrm{~S}$ rDNA sequence of B. mycoides (AB021192) was identical to that of B. weihenstephanensis (19 to $1531 \mathrm{bp}$ of AB021199), 
so the former was omitted. $\operatorname{Tr} \mathrm{N}+\mathrm{I}+\mathrm{G}$ (30) and GTR (General time reversible (31)) $+\mathrm{I}+\mathrm{G}$ models were selected according to hLRT and AIC of Modeltest 3.7, respectively. The Bayesian tree (Fig. 1.) was inferred by the GTR $+\mathrm{I}+\mathrm{G}$ model while NJ (Fig. 2.) and ME (Fig. 3.) trees were inferred by the $\mathrm{TrN}+\mathrm{I}+\mathrm{G}$ model (Gamma distribution shape parameter = $0.5854)$.

Although the phylogeny of some bacteria was different among the trees (Fig.1. to Fig. 5.), the phylogeny of most bacteria studied was consistent. Therefore, nine groups could be set up from 181 taxa. Holder and Lewis (11) held that ML and Bayesian approaches were more advantageous than $\mathrm{NJ}$, ME or MP methods, which was supported by the comparison of the five evolutionary trees. The Bayesian analysis of the 16S rDNA data set (181 taxa, 1603 sites) yielded a tree that supported with weak posterior probability $(\mathrm{PP}=0.5)$ the monophyly of nine groups (Fig. 1a). In general, the supports for the different groups were stronger in the Bayesian tree than other trees. This was particularly noticeable for Group 6 $(\mathrm{PP}=1)$ and Group $7(\mathrm{PP}=0.98)$ (Fig. 1e). Only in Bayesian tree were the supports (PP) for every group except Group 6 and Group 8 more than 0.5 . We did not find any case where the other trees provided much stronger supports than the Bayesian tree for a given node in agreement with the general trend observed in the comparisons among these measures of statistical supports (16). The topology of the ML tree was similar with that of the Bayesian tree and the bootstrap supports of the ML tree were higher than those of NJ, ME or MP trees.

The Bayesian tree demonstrated that Bacillus was not a monophyletic group. The species in Group 4, 6 and 9 had similarities in their respective phenotypes while the species in other groups differed much in their phenotypes, which were in agreement with the results of Goto et al. (9) and $\mathrm{Xu}$ and Côté (34).
Stackebrandt and Swiderski (27) suggested Bacillus RNA group 1 (1) should be divided into at least four subgroups; while Fig. 1. demonstrated that the previous RNA group 1 harbored Group 1, 2, 3 and 5. (Note Group 2 also contained the previous RNA group 2). These four groups constituted the core of Bacillus, which embraced approximately $65 \%$ of the Bacillus species.

Group 1 (28 species) contained B. subtilis, the type species of Bacillus, which was confirmed in other phylogenetic trees (Fig. 1b). Group 2 could be clearly divided into two clusters (Fig. 1c). B. cereus cluster included 14 Bacillus species (B. mycoides not shown in Fig. 1) while $B$. insolitus cluster, i.e. Bacillus RNA group 2, contained nine Bacillus species and seven other genera including non-sporeforming Kurthia and Caryophanon. Stackebrandt and Swiderski called this cluster "evolutionary enigma" and "interesting taxonomic problem" (27). If this cluster were not present, Group 1, 2, 3 and 5 would be united. The presence of the complex heterogeneous cluster was consistent with the results of Rheims et al. (24); La Duc et al. (13) and Zhang et al. (37). The heterogeneity of the cluster implied that nine Bacillus species might belong to several potential genera in order to make classification consistent with phylogeny. For example, $B$. insolitus and $B$. silvestris would have to be described as novel genera (27).

Group 3 (32 species) contained more species than any other groups (Fig. 1d), but it was not present in MP tree and less supported in $\mathrm{NJ}$ or $\mathrm{ME}$ tree (bootstrap proportion, $\mathrm{BP}<0.1)$. Group 5 was a minor group including eight species, which was accommodated in Group 1 in the NJ or MP trees. In the ME tree, Group 5 was closely related to Group 1 while in the ML or Bayesian tree, it was related to Group 2. It followed that Group 5 was an individual group that could not be merged into Group 1 or 2.

Group 4 consisted of thermophilic bacteria (Fig. 1b). The 16S rDNA sequences of $B$. thermantarcticus and Geobacillus 
thermoglucosidasius ATCC $43742^{\mathrm{T}}$ (X60641) showed a similarity of $98.3 \%$. According to the temperature and $\mathrm{pH}$ range suitable for growth and $\mathrm{G}+\mathrm{C}$ content $(17,18), B$. thermantarcticus might be transferred to Geobacillus. However, other four Bacillus species in this group, $B$. methanolicus, B. aeolius, B. alveayuensis and B. smithii could be obviously separated from Geobacillus by the low 16S rDNA similarities of $92 \%$. The presence of this Group 4 was consistent with the rRNA group 5 (1).

Group 6 (18 species) (Fig. 1e) was composed of halophilic or halotolerant Bacillus species except B. macyae (26). The presence of this Group 6 was consistent with the rRNA group 6 (19), which was also supported by the result of Ghosh et al. (8). Group 7 (7 species) was entirely composed of new published Bacillus species. The MP, ME and NJ trees demonstrated the close relationship between Group 6 and 7, but the two groups were entirely separated in the Bayesian or ML tree (Fig. 1e, Fig. 5). Not all the species in Group 7 were halotolerant except B. hwajinpoensis and B. decolorationis, which were included in Group 6 according to Yoon et al. (36). Nevertheless, our Bayesian tree and ML tree confirmed the position of the two halotolerant species was in Group 7 in agreement with the result of Nowlan et al. (21).

The $16 \mathrm{~S}$ rDNA sequences of the type strains in Group 8 and 9 , which had distinct insert sequences between 89 to 90 bp (B. subtilis AB042061 numbering), showed marked differences from those in other groups. Group 8 consisted of alkaliphilic and halotolerant bacteria (Fig. 1e) except that $B$. mannanilyticus was not halotolerant (20). Caldalkalibacillus thermarum was a thermophile and a peculiar member of Group 8, of which the 16S rDNA showed similarity of less than $92 \%$ to those of other Bacillus species in Group 8. Group 9 mainly consisted of the genera (excluding Bacillus) of Bacillaceae (Fig. 1f), but it had four Bacillus species: B. taeanensis, B. salarius, B. qingdaonensis and B. thermcloacae. The former three species were included in Group 8 using NJ methods by Lim et al. $(14,15)$ and Wang et al. (33), for the feasible reason that the authors did not use enough 16S rDNA sequences of the type strains of Group 9 for phylogenetic analysis. Therefore, the taxonomic positions of the four species were doubtful. The low $16 \mathrm{~S}$ rDNA similarities (less than 92.5\%) between the latter three species and their respective closest relatives in Bacillus suggested the latter three species were worthy to be reclassified.

There were four Bacillus species outside the nine groups in the 181 taxa phylogenetic trees (Fig. 1a). B. schlegelii and $B$. tusciae were thermophilic and facultatively chemolithoautotrophic bacteria with high $\mathrm{G}+\mathrm{C}$ content of the genome (2). Their $16 \mathrm{~S}$ rDNA sequences respectively showed a very low level of similarity (less than 90\%) with respect to other 180 sequences, which demonstrated that $B$. schlegelii and B. tusciae might well belong to two as-yetundescribed new genera. This opinion showed agreement with the views expressed by Stackebrandt and Swiderski (27) who held that B. schlegelii, B. tusciae and B. thermcloacae were potential new genera. $B$. edaphicus and $B$. mucilaginosus were always clustered with Paenibacillus polymyxa, and their relatively high $16 \mathrm{~S}$ rDNA sequence similarity values (96-97\%) to the nearest relatives ( $P$. elgii and $P$. chinjuensis, respectively) indicated that $B$. edaphicus and B. mucilaginosus might be transferred into Paenibacillus. The facts mentioned above revealed that at least nine Bacillus species (one in Group 4, four in Group 9 and four outside 9 groups) might not be really Bacillus species. Their phylogenetic positions would not be determined pending further polyphasic taxonomic studies.

In the NJ and ME trees, Ureibacillus, B. thermcloacae and Exiguobacterium formed a clade with a bootstrap value of less than 50\%; while in the ML, MP and Bayesian trees, Ureibacillus was in Group 2 and the latter two were in Group 
9, where their phylogenetic positions were supported by BP or PP of more than $50 \%$. The phylogeny of five species was uncertain (Table 1). Low 16S rDNA sequences similarities $(<93 \%)$ were found between Sporolactobacillus inulinus and other 181 taxa. S. inulinus showed scanty growth in air, was catalase-negative and not thermophilic (12), which manifested different phenotypes from the species of Group 7 or Group 4. Moreover, in the Bayesian and ML trees, BP or PP (both less than 0.5) could not ensure its position between Group 7 and 9. B. infernus, B. thermoamylovorans, $B$. coagulans and B. azotoformans were in their respective groups of the Bayesian tree with PP of more than 0.5 but their positions could not be supported by BP of less than $50 \%$ in the NJ, ME, MP or ML tree. For example, the former three thermophilic bacteria were included in Group 4 with BP of less than $35 \%$. Therefore, their positions in the Bayesian tree were more credible. Originally, B. infernus was clustered with B. methanolicus (3) and B. thermoamylovorans was grouped with Geobacillus and Saccharococcus (5), but bootstrap analyses were not done in the studies.

The evolutionary relationships among the nine groups differed much in the five phylogenetic trees. However, it was noteworthy that Group 8 was always an outlier of the other eight groups. Because of relatively high PP of more than 0.5, the phylogenetic relationships illustrated by the Bayesian tree, which agreed well with the ML tree, were more believable. In the five evolutionary trees, the phylogeny of the genera in Bacillales did not conform to the current wellknown taxonomic system (7) (Table 2). The genera in Bacillaceae except Bacillus were mainly in Group 9, 2 and 4, while Vulcanibacillus was outside the nine groups, suggesting that it should be removed from Bacillaceae. Caryophanaceae and Planococcaceae (represented by Kurthia) were clustered in Group 2, confirming the result of Yoon et al. (35) and implying that they might be accommodated in Bacillaceae.

Table 1 Disputable positions of 5 species in 5 phylogenetic trees.

\begin{tabular}{lccccc}
\hline & Bayesian & ML & ME & NJ & MP \\
\hline B. infernus & Group 3 & Group 3 & Group 4 & Group 3 & Group 4 \\
B. thermoamylovorans & Group 4 & Group 1 & Group 4 & Group 4 & Group 1 \\
B. coagulans & Group 1 & Group 1 & Group 4 & Group 4 & Group 1 \\
B. azotoformans & Group 5 & Group 2 & Group 3 & Group 3 & Group 3 \\
S. inulinus & $\mathrm{N}^{\mathrm{a}}$ & $\mathrm{N}^{\mathrm{a}}$ & Group 7 & Group 4 & Group 7 \\
\hline
\end{tabular}

a N, Not included in any group 
Wang, W. et al

Table 2 The relationship between obtained Bacillus species phylogeny and the current taxonomy.

\begin{tabular}{cc}
\hline Group number & Composition \\
\hline 1 & 5 genus from Bacillaceae, 1 genus from Caryophanaceae, 1 genus from Planococcaceae \\
3 & Bacillus \\
4 & 4 genus belong to Family Bacillaceae \\
5 & Bacillus \\
6 & Bacillus \\
7 & Bacillus \\
8 & 2 genus from Alicyclobacillaceae, 4 genus from Paenibacillaceae, 2 genus from Bacillaceae \\
9 & 25 genus belong to Family Bacillaceae \\
\hline
\end{tabular}

(a)

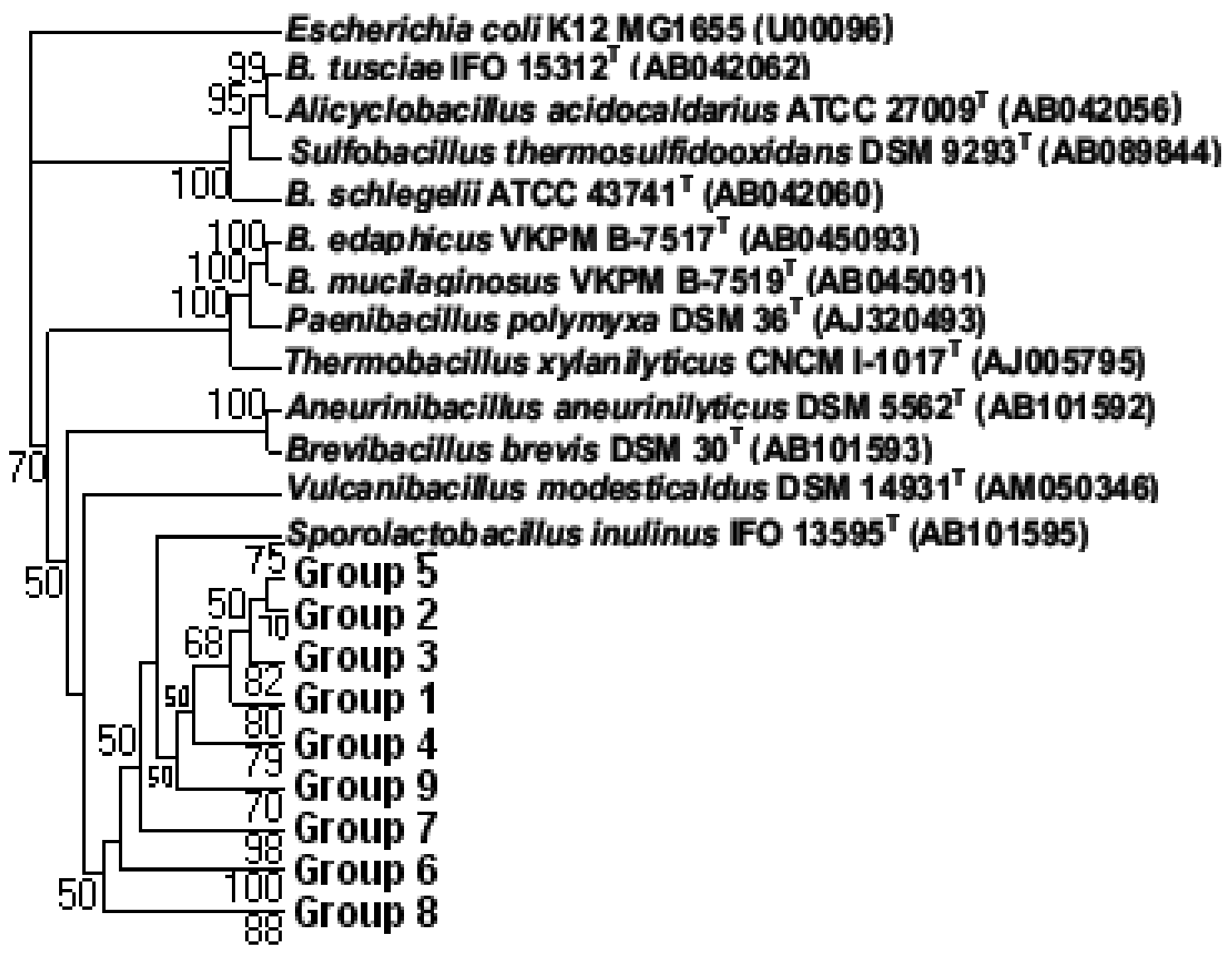


(b)

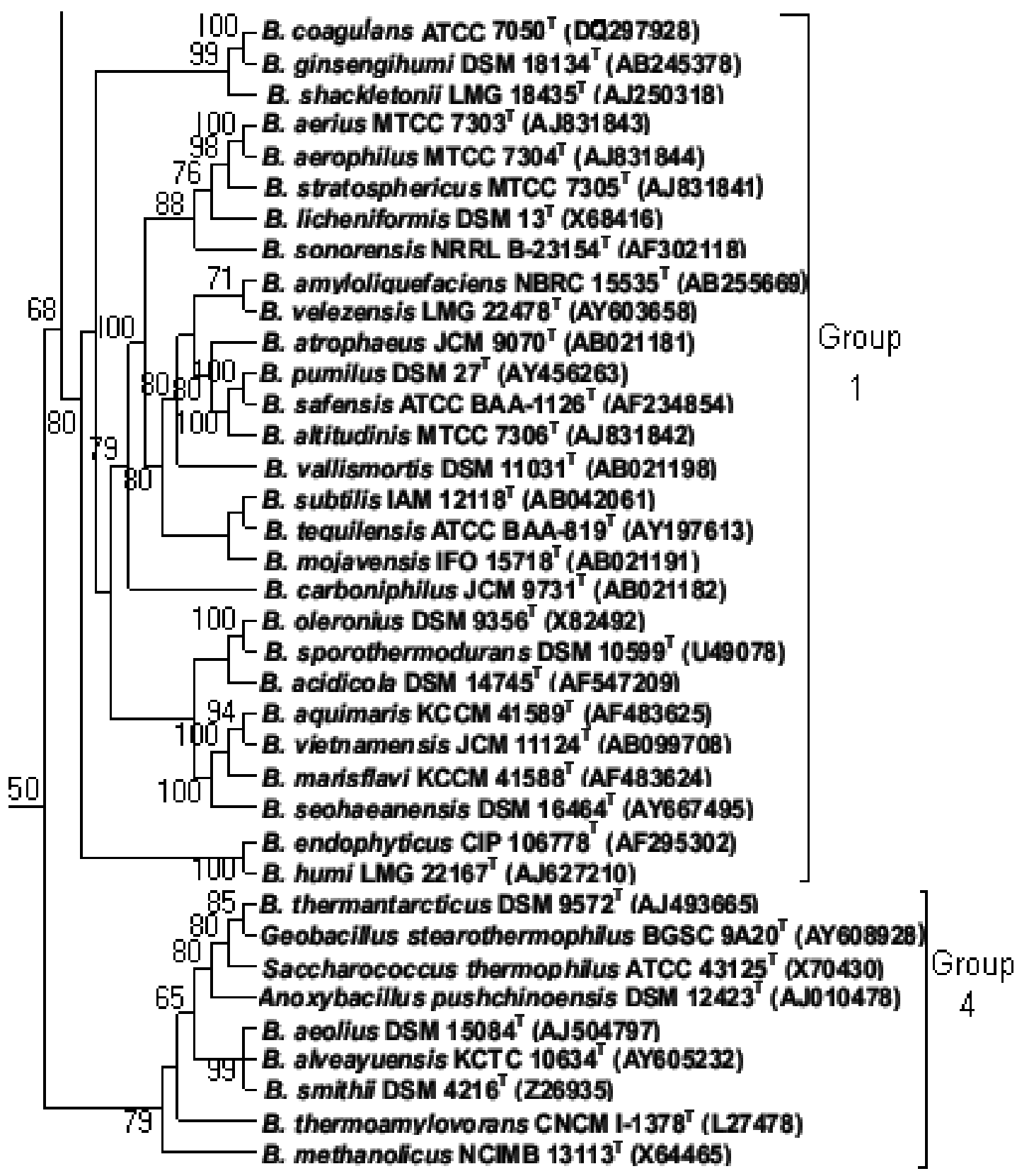


(c)

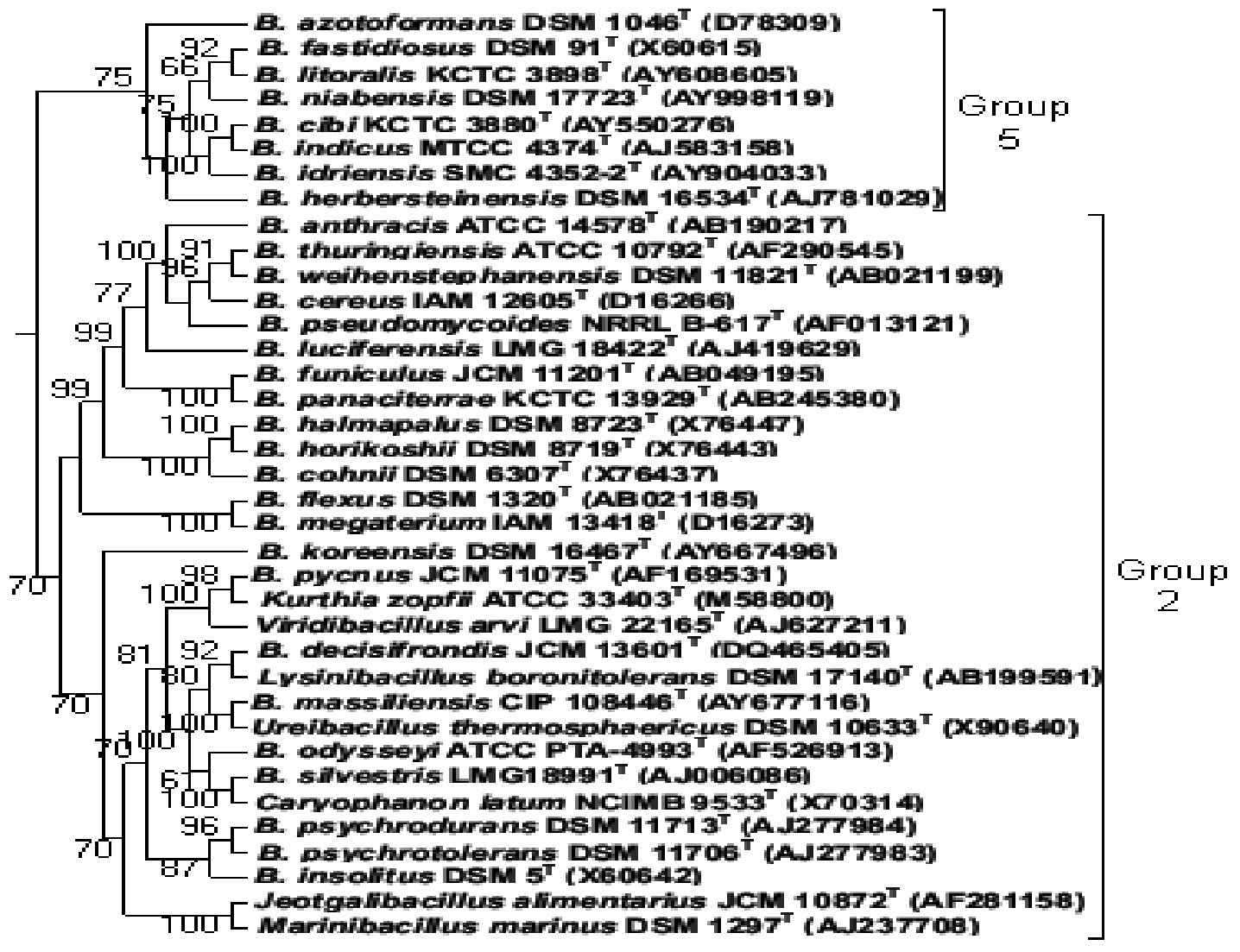

(d)

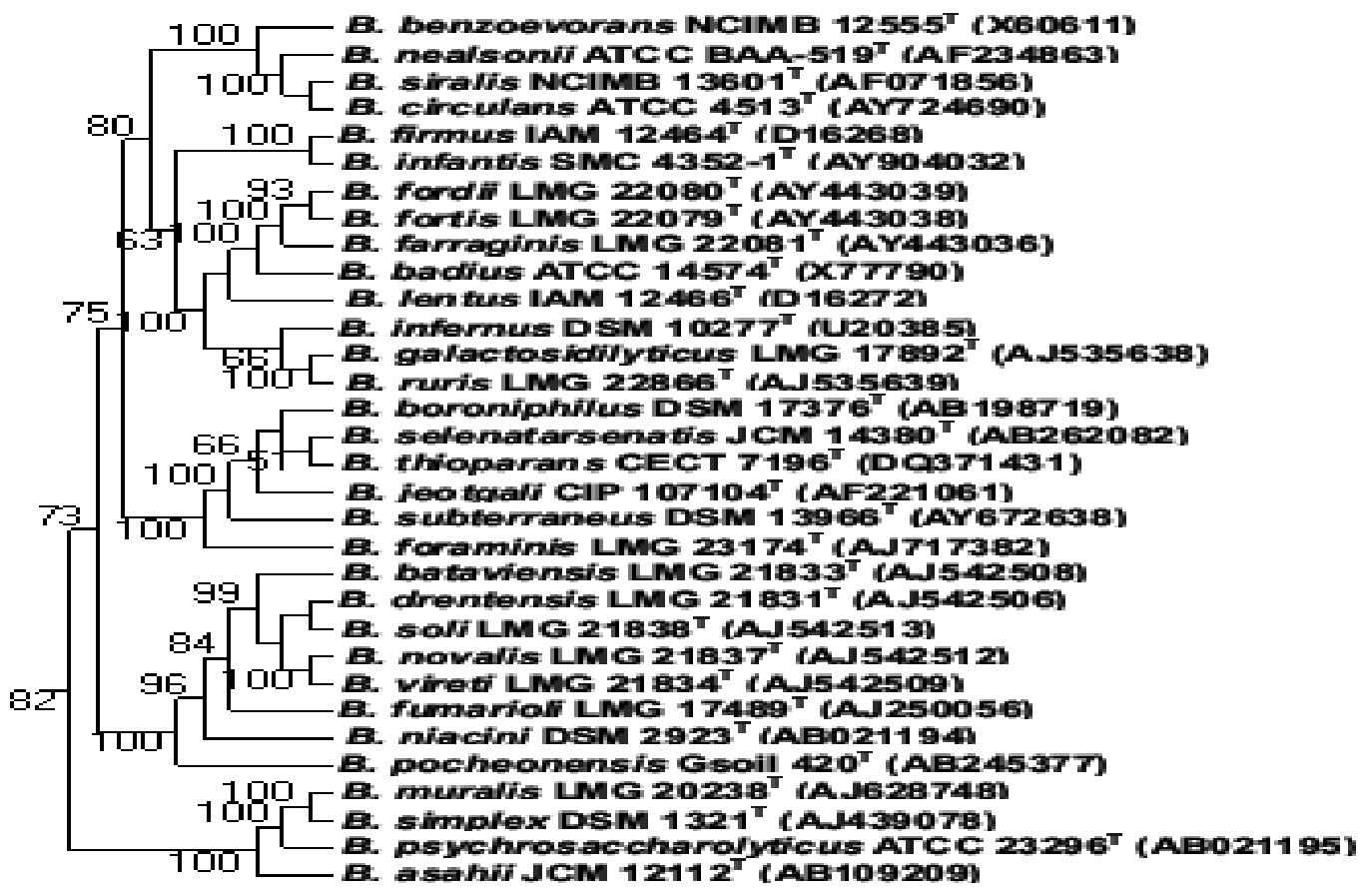


(e)

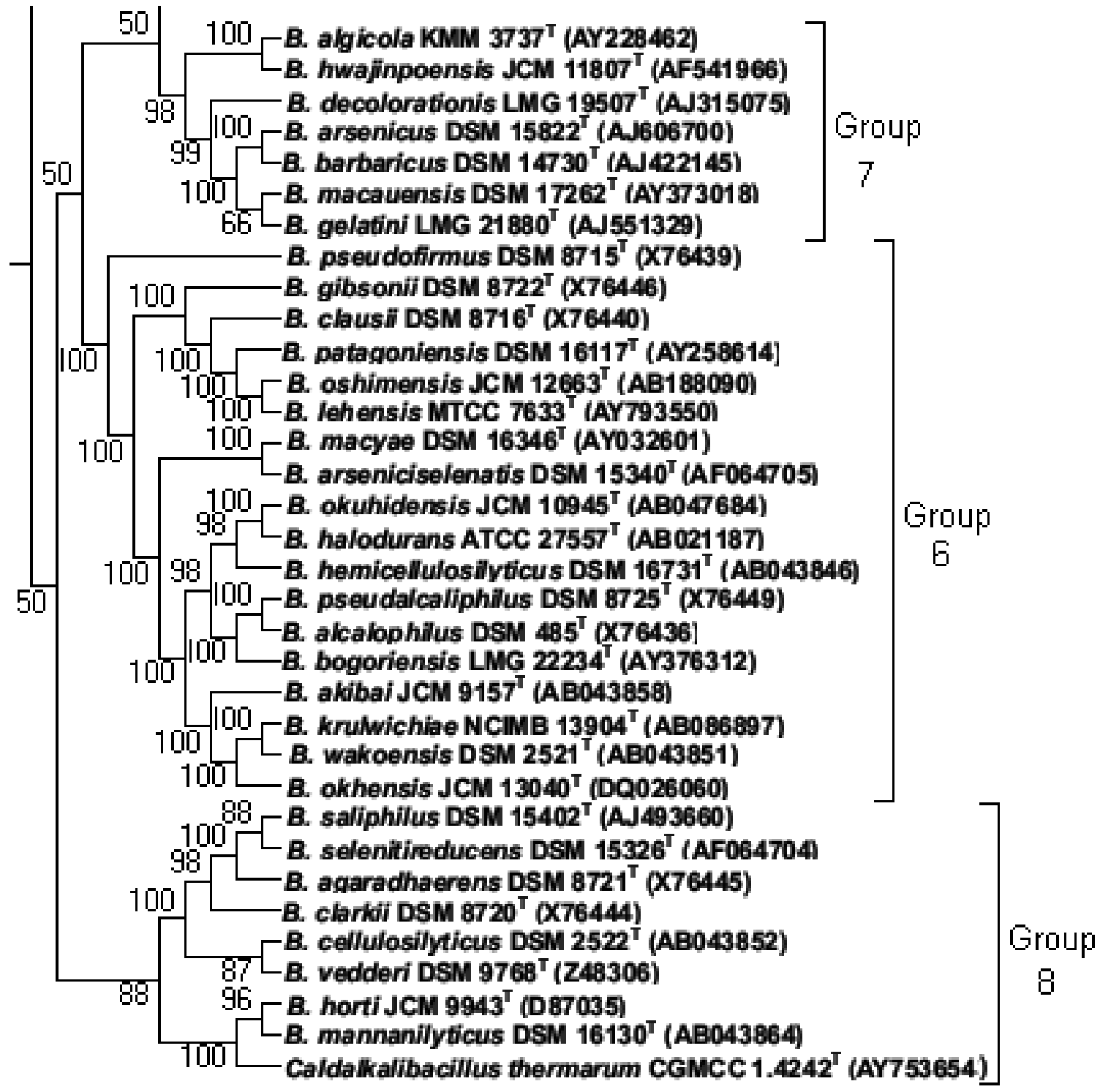


(f)

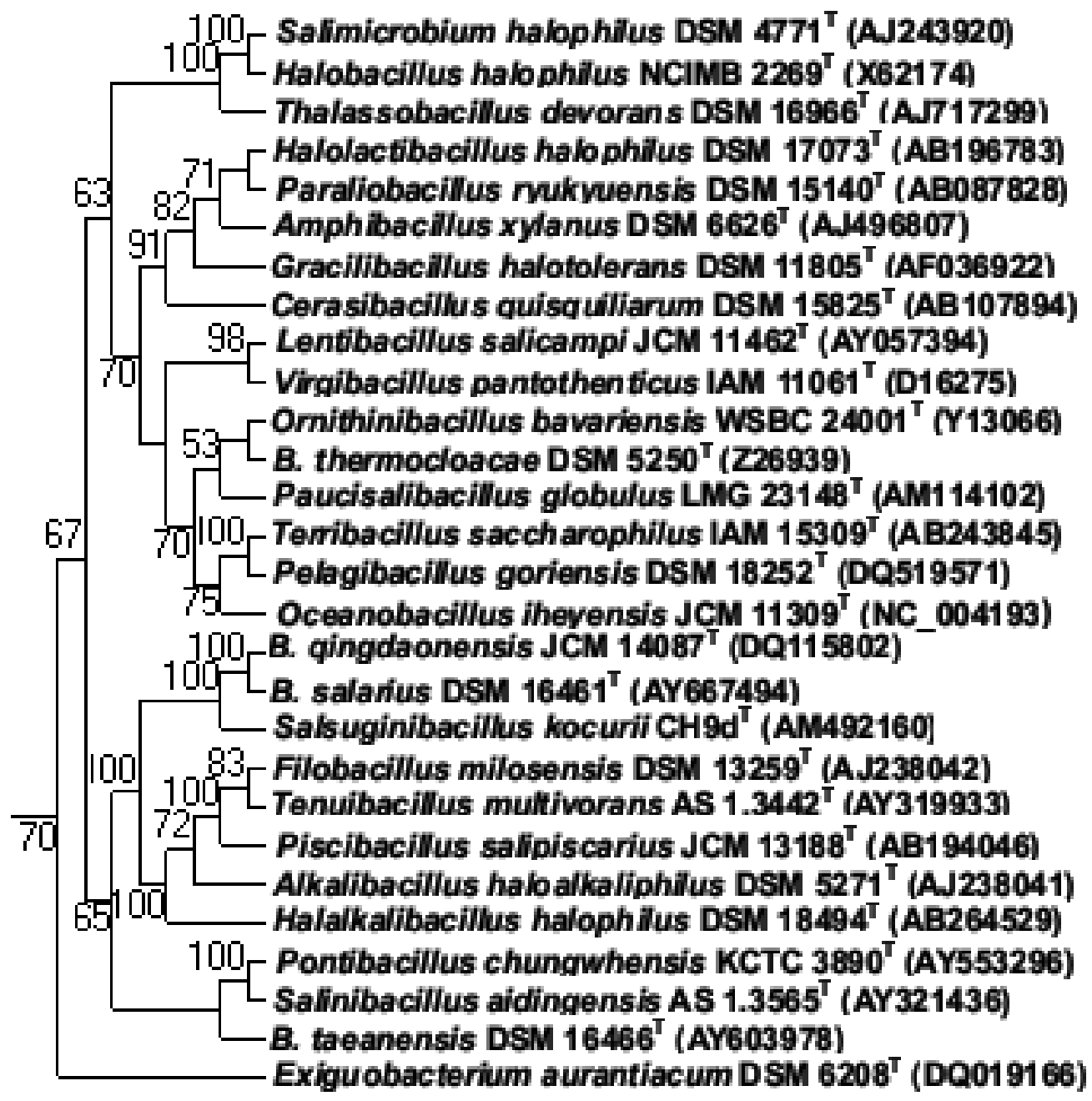

Figure 1. Bayesian cladistic tree constructed with the $16 \mathrm{~S}$ rDNA sequences of the type strains of Bacillus species and related genera (181 taxa, 1603 sites; GTR $+\mathrm{I}+\mathrm{G}$ plus covarion model) demonstrating 9 groups (a), and the species in every group were illustrated as (b) Group 1 and 4, (c) Group 2 and 5, (d) Group 3, (e) Group 6, 7 and 8, and (f) Group 9. Bootstrap confidence levels greater than $50 \%$ are indicated at the internodes. 


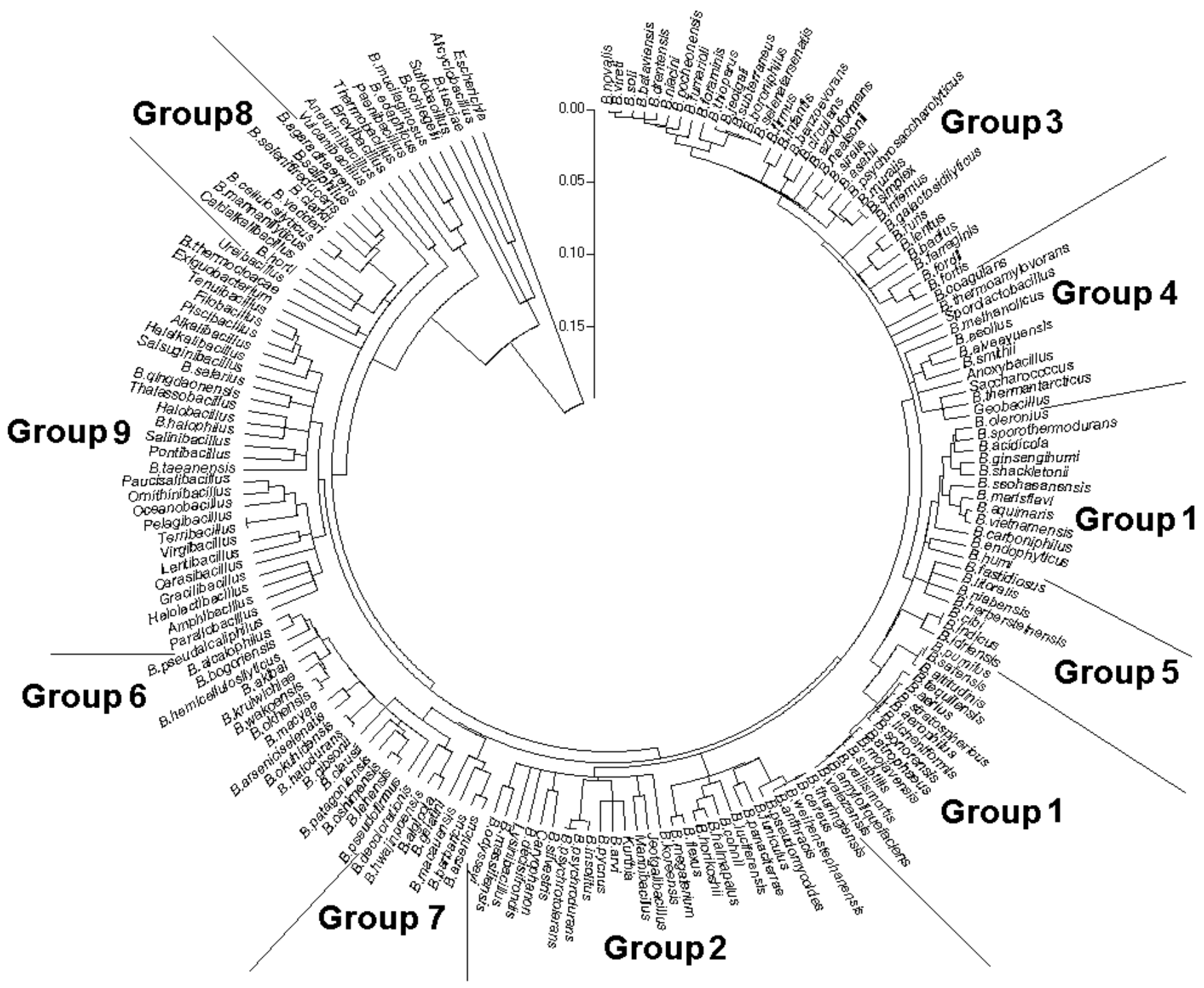

Figure 2. 16S rDNA neighbor-joining tree (based on 1000 bootstrap replications). The differences in the composition bias among sequences were considered in evolutionary comparisons. Alignment gaps and missing data were eliminated in pairwise sequence comparisons. Bar, 0.05 changes per nucleotide position. 
Wang, W. et al

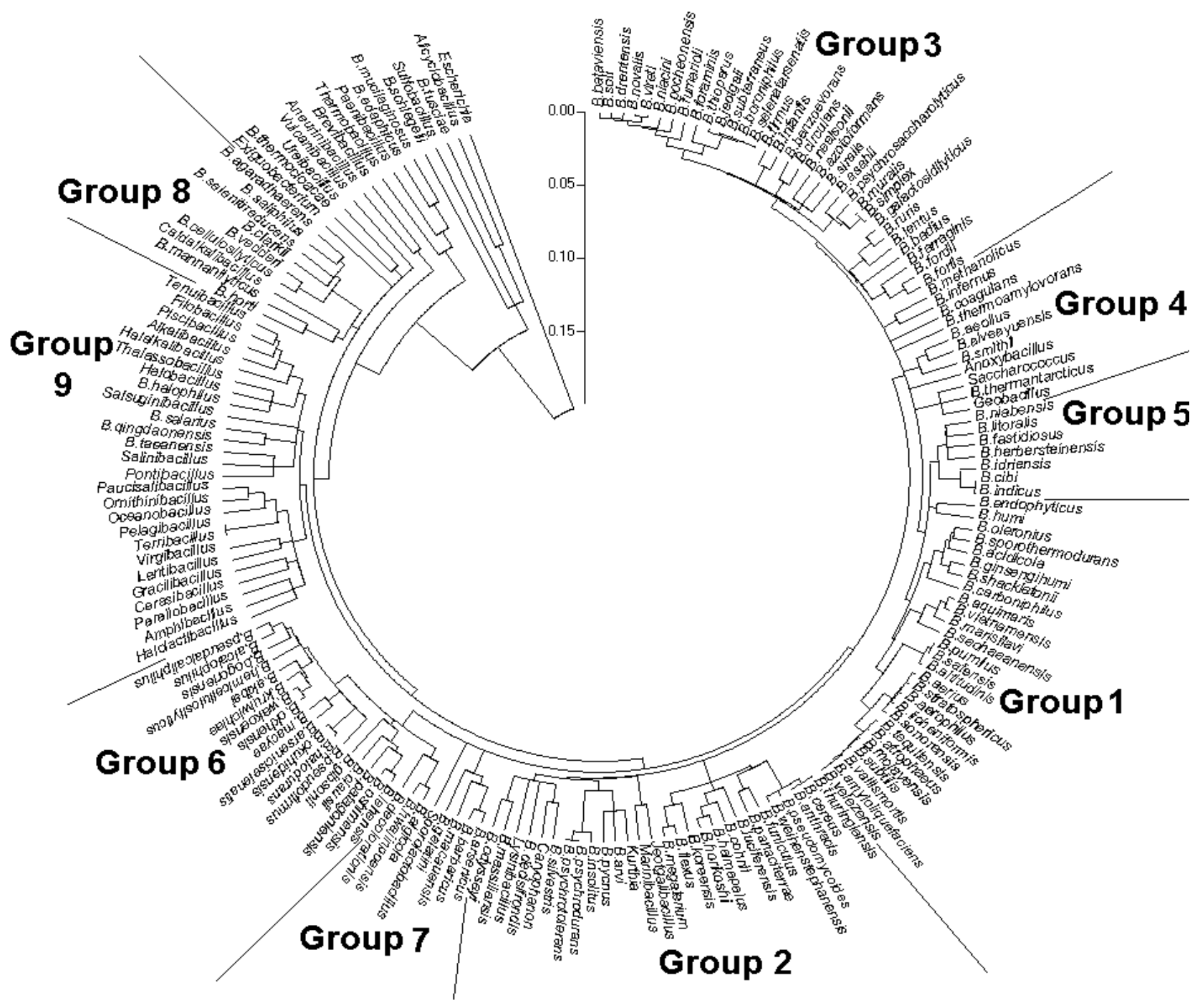

Figure 3. 16S rDNA minimum evolution tree (based on 1000 bootstrap replications). The tree was searched using the CloseNeighbor-Interchange algorithm at a search level of 2. The differences in the composition bias among sequences were considered in evolutionary comparisons. Alignment gaps and missing data were eliminated in pairwise sequence comparisons. Bar, 0.05 changes per nucleotide position. 


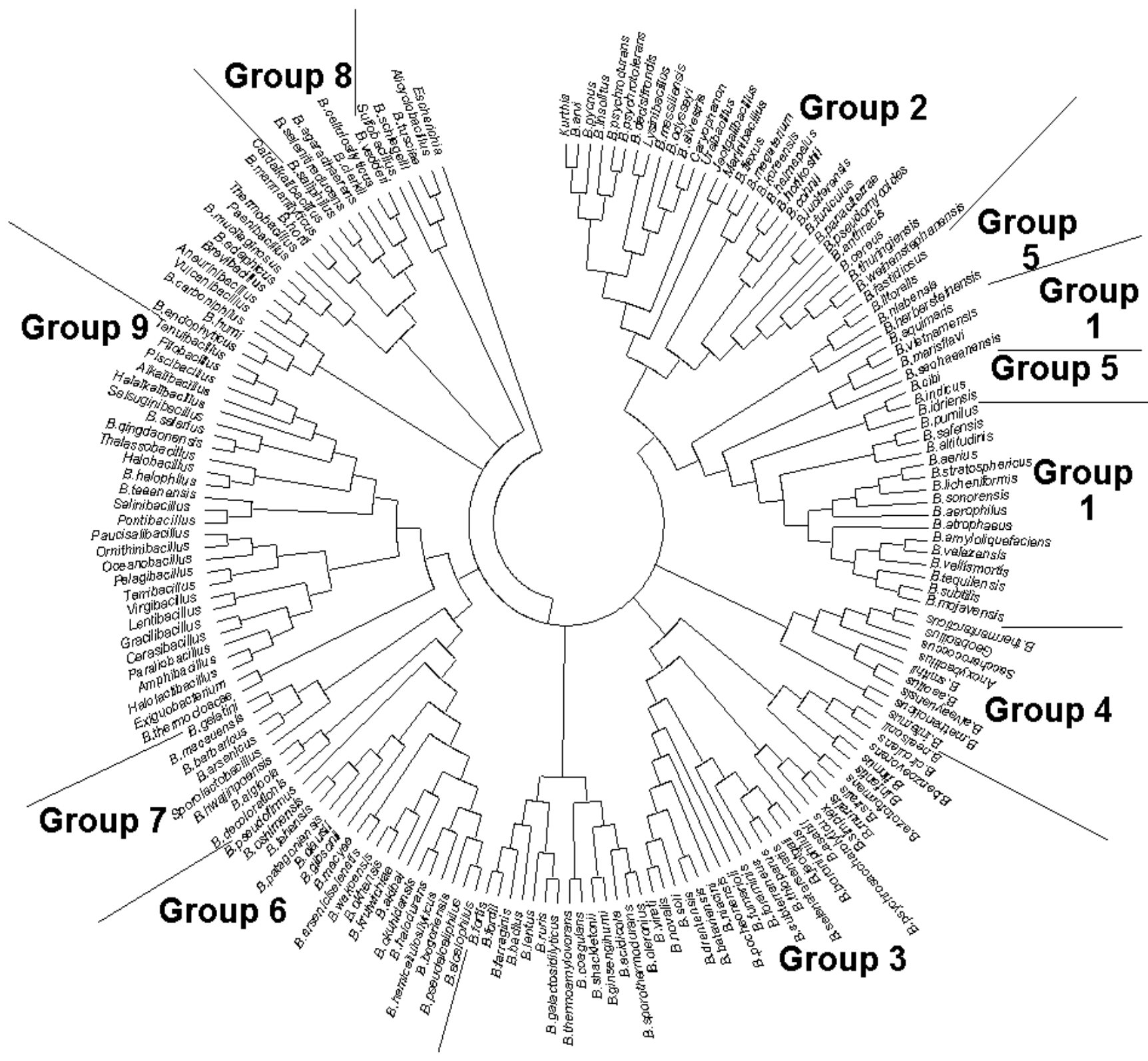

Figure 4. The maximum-parsimony phylogenetic tree derived from $16 \mathrm{~S}$ rDNA sequences. The tree (based on 1000 bootstrap replications) was obtained using the Close-Neighbor-Interchange algorithm with search level 3 in which the initial trees were obtained with the random addition of sequences (10 replicates). All alignment gaps were treated as missing data. Escherichia coli was used as the outgroup. 
Wang, W. et al

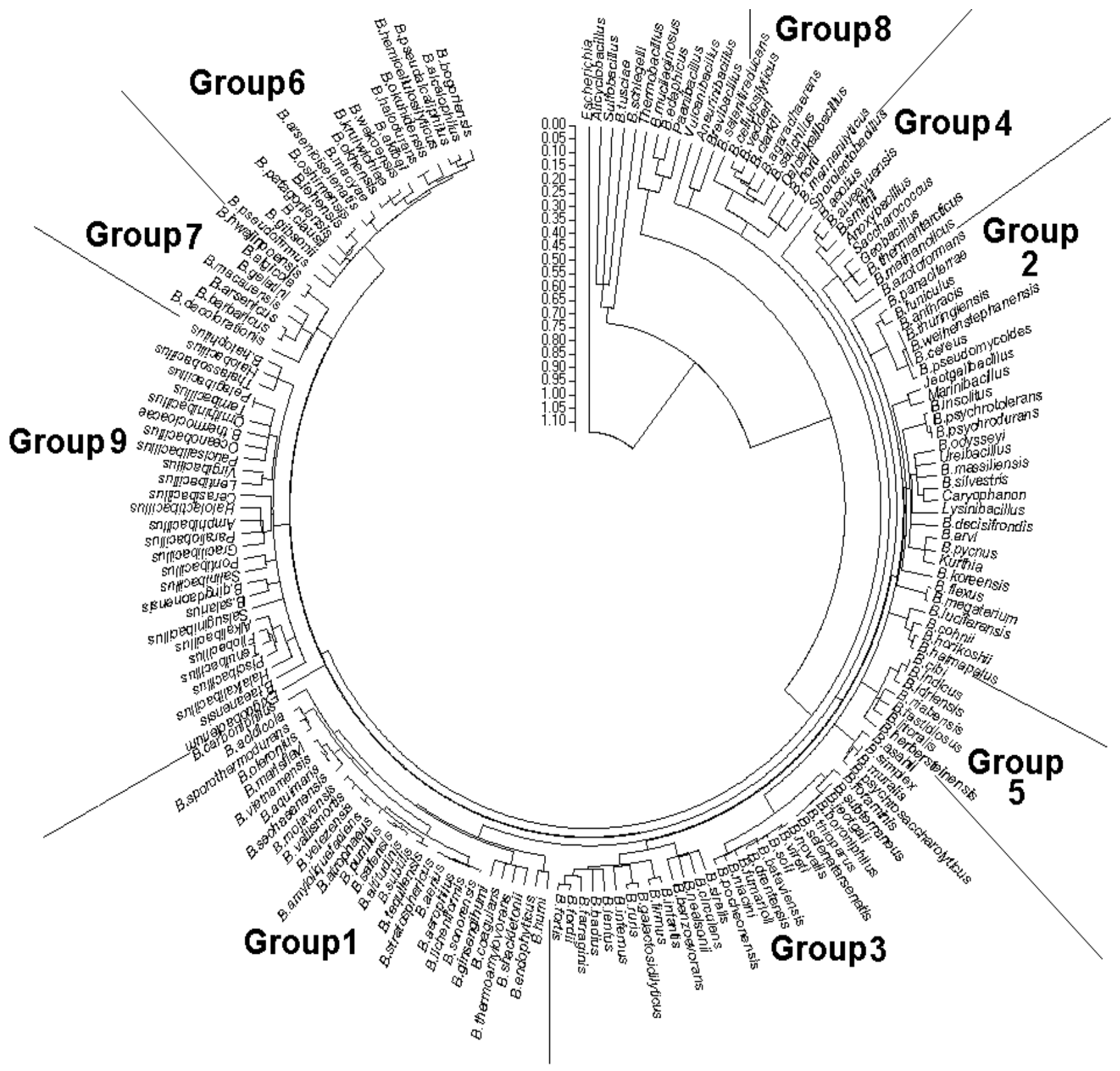

Figure 5. 16S rDNA maximum likelihood tree (based on 100 bootstrap replications). The tree was searched using RAxML-VIHPC version 4.0.0 (Stamatakis, 2007). RAxML executed 100 rapid bootstrap inferences and thereafter a thorough ML search with GTR model of nucleotide substitution. All free model parameters was estimated by RaxML. Bar, 0.01 change per nucleotide position. 


\section{ACKNOWLEDGEMENTS}

We thank Gao Qiang, Ji Cunpeng and Hao Jianhua for collaboration on computation. This work was supported by the National High Technology Research and Development Program of China (863 Program) in Marine Technology Area during the 11th Five-year Plan Period (2007AA091602).

\section{RESUMO}

\section{Relações filogenéticas entre espécies de Bacillus e gêneros relacionados baseadas em sequencias 16S rDNA}

Árvores utilizando os métodos de neighbor-joining, máxima parcimônia, evolução mínima, máxima verossimilhança e bayesiana, construídas baseadas em seqüências de rDNA 16S de 181 linhagens-tipo de espécies de Bacillus e taxa relacionados, mostraram a formação de nove grupos filogenéticos. A análise filogenética mostrou que Bacillus não é um grupo monofilético. $B$. subtilis se colocou no Grupo 1. Grupos 4, 6 e 8, respectivamente, consistiram de bacilos termofílicos, halofílicos ou halotolerantes e alcalifílicos. Grupos 2, 4 e 8 consistindo de espécies de Bacillus e gêneros relacionados demonstraram que o sistema taxonômico corrente não concorda perfeitamente com as árvores evolucionárias por rDNA $16 \mathrm{~S}$. A posição de Caryophanaceae e Planococcaceae no Grupo 2 sugere que estes podem ser transferidos para Bacillaceae, e a heterogeneidade do Grupo 2 implica em que algumas espécies de Bacillus neste grupo podem pertencer a vários novos gêneros. O Grupo 9 foi principalmente composto de gêneros de Bacillaceae (excluindo Bacillus), portanto algumas espécies de Bacillus no Grupo 9: B. salarius, B. qingdaonensis e $B$. thermcloacae podem não pertencer a Bacillus. Quatro espécies de Bacillus, B. schlegelii, B. tusciae, B. edaphicus e B. mucilaginosus foram claramente colocadas fora dos nove grupos.

Palavras-chave: filogenia de Bacillus, inferência Bayesiana, árvores evolucionárias, 16S rDNA

\section{REFERENCES}

1. Ash, C.; Farrow, J.A.E.; Wallbanks, S.; Collins, M.D. (1991). Phylogenetic heterogeneity of the genus Bacillus revealed by comparative analysis of small-subunit-ribosomal RNA sequences. Lett. Appl. Microbiol., 13(4), 202-206.

2. Bonjour, F.; Aragno, M. (1984). Bacillus tusciae, a new species of thermoacidophilic, facultatively chemolithoautotrophic hydrogen oxidizing sporeformer from a geothermal area. Arch. Microbiol., 139(4), 397-401.

3. Boone, D.R.; Liu, Y.; Zhao, Z.J.; Balkwill, D.L.; Drake, G.R.; Stevens, T.O.; Aldrich, H.C. (1995). Bacillus infernus sp. nov., an Fe(III)- and Mn(IV)-reducing anaerobe from the deep terrestrial subsurface. Int. J. Syst. Bacteriol., 45(3), 441-448.

4. Chun, J.; Lee, J.H.; Jung, Y.; Kim, M.; Kim, S.; Kim, B.K.; Lim, Y.W. (2007). EzTaxon: a web-based tool for the identification of prokaryotes based on 16S ribosomal RNA gene sequences. Int. J. Syst. Evol. Microbiol., 57(10), 2259-2261.

5. Combet-Blanc, Y.; Ollivier, B.; Streicher, C.; Patel, B.K.; Dwivedi, P.P.; Pot, B.; Prensier, G.; Garcia, J.L. (1995). Bacillus thermoamylovorans sp. nov., a moderately thermophilic and amylolytic bacterium. Int. J. Syst. Bacteriol., 45(1), 9-16.

6. Euzeby, J.P. (1997). List of Bacterial Names with Standing in Nomenclature: a folder available on the Internet. Int J Syst Bacteriol, 47(2), 590-592.

7. Garrity, G.M.; Lilburn, T.G.; Cole, J.R.; Harrison, S.H.; Euzeby, J.; Tindall, B.J. (2007). Taxonomic Outline of the Bacteria and Archaea (Release 7.7 ed.): Michigan State University Board of Trustees.

8. Ghosh, A.; Bhardwaj, M.; Satyanarayana, T.; Khurana, M.; Mayilraj, S.; Jain, R.K. (2007). Bacillus lehensis sp. nov., an alkalitolerant bacterium isolated from soil. Int. J. Syst. Evol. Microbiol., 57(2), 238242.

9. Goto, K.; Omura, T.; Hara, Y.; Sadaie, Y. (2000). Application of the partial 16S rDNA sequence as an index for rapid identification of species in the genus Bacillus. J. Gen. Appl. Microbiol., 46(1), 1-8. 
10. Hall, T.A. (1999). BioEdit: a user-friendly biological sequence alignment editor and analysis program for Windows 95/98/NT. Nucl. Acids. Symp. Ser., 41, 95-98.

11. Holder, M.; Lewis, P.O. (2003). Phylogeny estimation: traditional and Bayesian approaches. Nat. Rev. Genet., 4(4), 275-284.

12. Kitahara, K.; Suzuki, J. (1963). Sporolactobacillus nov. subgen. J. Gen. Appl. Microbiol., 9(1), 59-71.

13. La Duc, M.T.; Satomi, M.; Venkateswaran, K. (2004). Bacillus odysseyi sp. nov., a round-spore-forming bacillus isolated from the Mars Odyssey spacecraft. Int. J. Syst. Evol. Microbiol., 54(1), 195-201.

14. Lim, J.M.; Jeon, C.O.; Kim, C.J. (2006). Bacillus taeanensis sp. nov., a halophilic Gram-positive bacterium from a solar saltern in Korea. Int. J. Syst. Evol. Microbiol., 56(12), 2903-2908.

15. Lim, J.M.; Jeon, C.O.; Lee, S.M.; Lee, J.C.; Xu, L.H.; Jiang, C.L.; Kim, C.J. (2006). Bacillus salarius sp. nov., a halophilic, spore-forming bacterium isolated from a salt lake in China. Int. J. Syst. Evol. Microbiol., 56(2), 373-377.

16. Moreira, D.; von der Heyden, S.; Bass, D.; Lopez-Garcia, P.; Chao, E.; Cavalier-Smith, T. (2007). Global eukaryote phylogeny: Combined small- and large-subunit ribosomal DNA trees support monophyly of Rhizaria, Retaria and Excavata. Mol. Phylogenet. Evol., 44(1), 255266.

17. Nazina, T.N.; Tourova, T.P.; Poltaraus, A.B.; Novikova, E.V.; Grigoryan, A.A.; Ivanova, A.E.; Lysenko, A.M.; Petrunyaka, V.V.; Osipov, G.A.; Belyaev, S.S.; Ivanov, M.V. (2001). Taxonomic study of aerobic thermophilic bacilli: descriptions of Geobacillus subterraneus gen. nov., sp. nov. and Geobacillus uzenensis sp. nov. from petroleum reservoirs and transfer of Bacillus stearothermophilus, Bacillus thermocatenulatus, Bacillus thermoleovorans, Bacillus kaustophilus, Bacillus thermodenitrificans to Geobacillus as the new combinations G. stearothermophilus, G. thermocatenulatus, G. thermoleovorans, G. kaustophilus, G. thermoglucosidasius and G. thermodenitrificans. Int. J. Syst. Evol. Microbiol., 51(2), 433-446.

18. Nicolaus, B.; Lama, L.; Esposito, E.; Manca, M.C.; di Prisco, G.; Gambacorta, A. (1996). "Bacillus thermoantarcticus" sp. nov., from Mount Melbourne, Antarctica: a novel thermophilic species. Polar Biol., 16(2), 101-104.

19. Nielsen, P.; Rainey, F.A.; Outtrup, H.; Priest, F.G.; Fritze, D. (1994). Comparative 16S rDNA sequence analysis of some alkaliphilic bacilli and the establishment of a sixth rRNA group within the genus Bacillus. FEMS Microbiol. Lett., 117(1), 61-65.

20. Nogi, Y.; Takami, H.; Horikoshi, K. (2005). Characterization of alkaliphilic Bacillus strains used in industry: proposal of five novel species. Int. J. Syst. Evol. Microbiol., 55(6), 2309-2315.
21. Nowlan, B.; Dodia, M.S.; Singh, S.P.; Patel, B.K. (2006). Bacillus okhensis sp. nov., a halotolerant and alkalitolerant bacterium from an Indian saltpan. Int. J. Syst. Evol. Microbiol., 56(5), 1073-1077.

22. Posada, D.; Crandall, K.A. (1998). MODELTEST: testing the model of DNA substitution. Bioinformatics, 14(9), 817-818.

23. Priest, F.G.; Goodfellow, M.; Todd, C. (1988). A numerical classification of the genus Bacillus. J. Gen. Microbiol., 134(7), $1847-$ 1882.

24. Rheims, H.; Fruhling, A.; Schumann, P.; Rohde, M.; Stackebrandt, E. (1999). Bacillus silvestris sp. nov., a new member of the genus Bacillus that contains lysine in its cell wall. Int. J. Syst. Bacteriol., 49(2), 795-802

25. Ronquist, F.; Huelsenbeck, J.P. (2003). MrBayes 3: Bayesian phylogenetic inference under mixed models. Bioinformatics, 19(12), 1572-1574.

26. Santini, J.M.; Streimann, I.C.; vanden Hoven, R.N. (2004). Bacillus macyae sp. nov., an arsenate-respiring bacterium isolated from an Australian gold mine. Int. J. Syst. Evol. Microbiol., 54(6), 2241-2244.

27. Stackebrandt, E.; Swiderski, J. (2002). From phylogeny to systematics: the dissection of the genus Bacillus. In Berkeley R, Heyndrickx M, Logan N \& De Vos P (Eds.), Applications and systematics of Bacillus and relatives (pp. 8-22). Malden: Blackwell.

28. Stamatakis, A. (2006). RAxML-VI-HPC: maximum likelihood-based phylogenetic analyses with thousands of taxa and mixed models. Bioinformatics, 22(21), 2688-2690.

29. Tamura, K.; Dudley, J.; Nei, M.; Kumar, S. (2007). MEGA4: Molecular Evolutionary Genetics Analysis (MEGA) software version 4.0. Mol. Biol. Evol., 24(8), 1596-1599.

30. Tamura, K.; Nei, M. (1993). Estimation of the number of nucleotide substitutions in the control region of mitochondrial DNA in humans and chimpanzees. Mol. Biol. Evol., 10(3), 512-526.

31. Tavaré, S. (1986). Some probabilistic and statistical problems on the analysis of DNA sequences. Lect. Math. Life Sc., 17, 262-272.

32. Thompson, J.D.; Gibson, T.J.; Plewniak, F.; Jeanmougin, F.; Higgins, D.G. (1997). The CLUSTAL_X windows interface: flexible strategies for multiple sequence alignment aided by quality analysis tools. Nucleic Acids Res., 25(24), 4876-4882.

33. Wang, Q.F.; Li, W.; Liu, Y.L.; Cao, H.H.; Li, Z.; Guo, G.Q. (2007). Bacillus qingdaonensis sp. nov., a moderately haloalkaliphilic bacterium isolated from a crude sea-salt sample collected near Qingdao in eastern China. Int. J. Syst. Evol. Microbiol., 57(5), 1143-1147.

34. Xu, D.; Cote, J.C. (2003). Phylogenetic relationships between Bacillus species and related genera inferred from comparison of 3 ' end $16 \mathrm{~S}$ 
rDNA and $5^{\prime}$ end 16S-23S ITS nucleotide sequences. Int. J. Syst. Evol. Microbiol., 53(3), 695-704.

35. Yoon, J.H.; Kang, S.S.; Lee, K.C.; Lee, E.S.; Kho, Y.H.; Kang, K.H.; Park, Y.H. (2001). Planomicrobium koreense gen. nov., sp. nov., a bacterium isolated from the Korean traditional fermented seafood jeotgal, and transfer of Planococcus okeanokoites (Nakagawa et al. 1996) and Planococcus mcmeekinii (Junge et al. 1998) to the genus Planomicrobium. Int. J. Syst. Evol. Microbiol., 51(4), 1511-1520.
36. Yoon, J.H.; Kim, I.G.; Kang, K.H.; Oh, T.K.; Park, Y.H. (2004). Bacillus hwajinpoensis sp. nov. and an unnamed Bacillus genomospecies, novel members of Bacillus rRNA group 6 isolated from sea water of the East Sea and the Yellow Sea in Korea. Int. J. Syst. Evol. Microbiol., 54(3), 803-808.

37. Zhang, L.; Xu, Z.; Patel, B.K. (2007). Bacillus decisifrondis sp. nov., isolated from soil underlying decaying leaf foliage. Int. J. Syst. Evol. Microbiol., 57(5), 974-978. 